\title{
Economic and Financial Adjustments in Europe: An Introduction
}

\author{
António Afonso ${ }^{1}$. José Alves ${ }^{2}$. João Jalles ${ }^{3}$ \\ Published online: 26 July 2021 \\ (c) Association for Comparative Economic Studies 2021
}

This special issue (SI) of Comparative Economic Studies includes eight research papers from the 8th UECE Conference on Economic and Financial Adjustments, organised by UECE - Research Unit on Complexity and Economics, at ISEG-Lisbon School of Economics and Management, Universidade de Lisboa, on 27 November 2020. ${ }^{1}$ We thank all the referees of this SI for their help in reading and commenting the papers in several rounds.

The paper by Jérôme Creel, who was a keynote speaker, recalls that recent empirical results on fiscal sustainability suggest it not to be a major concern for the $\mathrm{EU}$ in the short to medium-run, and he also stresses that fiscal dominance regimes do not lead to macroeconomic instability.

He equally argues that Europe should continue on the fiscal impetus they contributed to in 2020 by fostering coordination and transparency on EU fiscal policies, notably via a Fiscal Dialogue with the different EU Member States.

The paper by José Alves and Tomás Silva analyzes the relation between monetary policy and its transmission channels into both income and wealth inequality. Looking at the Euro Area between 1999 and 2017, the authors report that increases in asset prices, mainly equity, are relevant in explaining increases in income inequality. On the other hand, declining unemployment, due to monetary policy measures, avoided a higher increase in income inequality in the common currency area.

\footnotetext{
1 More information about the conference in here: https://uece2.rc.iseg.ulisboa.pt/events/2020/efae/conf2 020.html.

António Afonso

aafonso@iseg.ulisboa.pt

José Alves

jalves@iseg.ulisboa.pt

João Jalles

jjalles@iseg.ulisboa.pt

1 ISEG - Lisbon School of Economics and Management, Universidade de Lisboa, Lisbon, Portugal

2 REM - Research in Economics and Mathematics, Lisbon, Portugal

3 UECE - Research Unit on Complexity and Economics, Lisbon, Portugal
} 
In his paper, Carlos Marinheiro argues that the EU expenditure benchmark is a complex indicator, less suitable for the use at national level by Independent Fiscal Institutions. According to the author, one would need more transparency and simplification of this indicator to reduce the reliance on non-observable variables.

In their paper, António Afonso, João Jalles and Ana Venâncio assess the relevance of taxation for public spending efficiency in a sample of OECD economies over the 2003-2017 period. They study the determinants of DEA efficiency scores and find that inputs could be theoretically lower by approximately $32-34 \%$ and that expenditure efficiency is found to be negatively associated with direct and indirect taxes (with the same being true for social security contributions).

The paper by Nicolae-Bogdan Ianc studies the reasons of variation of direct taxto-GDP ratios in a panel of 46 countries, using the World Values Survey Wave 7 (2017-2020). One of such determinants stems from cultural diversity. Results show that, indeed, cultural attitudes should be considered when studying the level of direct tax revenues.

Joel Hellier uses a model in which households select their country of residence depending on income taxation and on the cost of migrating and living abroad. Making redistribution and progressivity contradictory, the model provides a new explanation for the concomitance of growing redistribution expenditure and growing inequality, and to the social democracy curse experienced by a number of advanced countries in the last three decades.

The paper by António Afonso, Maria João Guedes and Pankal C. Patel assesses if the four holidays revoked in Portugal in the period 2013-2015 had an effect on state-owned enterprises' (SOEs) labour productivity. Their results show no impact on labour productivity for either central or local and regional government managed SOEs.

Finally, Carolina Corea-Caro, Leandro Medina, Bennet Sutton and Marcos Poplawski Ribeiro examine how fiscal stimulus interacted with sectoral business cycle sensitivity has affected firms' sales and capital expenditures during the global financial crisis. For more than 17,253 non-financial firms in a sample of 45 advanced and emerging economies and relying on cross-sectional analyses, they report that reductions in structural fiscal balances are associated with higher firms' sales and capital expenditures (as percentage of their total assets).

Publisher's Note Springer Nature remains neutral with regard to jurisdictional claims in published maps and institutional affiliations. 